УДК372.881.1

\title{
ФОРМУВАННЯ У МАЙБУТНІХ УЧИТЕЛІВ АНГЛОМОВНОЇ КОМПЕТЕНТНОСТІ В ДІАЛОГІЧНОМУ МОВЛЕННІ: РЕЦЕПТИВНО-КОГНІТИВНА ДИФЕРЕНЦАЦІЯ
}

\author{
Щербина М. Б. \\ madina70@ukr.net \\ Київський національний лінгвістичний університет \\ Дата надходження 01.12.2018. Рекомендовано до друку 24.12.2018.
}

\begin{abstract}
Анотація. У статті представлено результати дослідження впливу індивідуальних особливостей когнітивних процесів студентів на їхнє учіння щодо формування компетентності в іншомовному діалогічному мовленні. Виокремлено пізнавальні процеси, які $є$ провідними під час сприймання навчального матеріалу. Проаналізовано залежність способу представлення діалогу-зразка від домінувальної перцептивної модальності студента. Представлено результати проведеного анкетування студентів з метою виявлення їхнього домінувального рецептивного каналу й подальшого розподілу їх на типологічні групи. На основі результатів проведеного анкетування теоретично обгрунтовано рецептивно-когнітивну диференціацію як вид диференційованого формування у майбутніх учителів англомовної компетентності в діалогічному мовленні. Засобом іiі реалізації обрано діалог-зразок.

Ключові слова: індивідуалізація, диференціація, іншомовне діалогічне мовлення, перцептивна модальність, діалог-зразок.
\end{abstract}

\section{Щербина М. Б. Киевский национальный лингвистический университет}

Формирование у будущих учителей англоязычной компетентности в диалогической речи: рецептивно-когнитивная дифференциация

Аннотация. В статье представлены результаты исследования влияния индивидуальных личностных когнитивных процессов студентов на их учебу, в частности формирование компетентности в иноязычной диалогической речи. Выделены познавательные процессы, которые являются ведущими в восприятии учебного материала. Проанализирована зависимость способа представления диалога-образца от доминирующей перцептивной модальности студента. Представлены результаты проведенного анкетирования студентов с целью выявления их доминирующего рецептивного канала и их дальнейшего распределения на типологическое группы. Основываясь на результатах проведенного анкетирования, теоретически обосновано рецептивно-когнитивную дифференциацию как вид дифференцированного формирования у будущих учителей англоязычной компетентности в диалогической речи. Средством ее реализации выбран диалог-образец.

Ключевые слова: индивидуализация, дифференциация, иноязычная диалогическая речь, перцептивная модальность, диалог-образец.

Shcherbyna M. Kyiv National Linguistic University

The development of the English-speaking interactional competence of the prospective teachers by means of receptive-cognitive differentiation

Abstract. Introduction. The Ukrainian education undergoes changes on all its levels. Following the European example, the Ukrainian society seeks motivated students who may become well-trained specialists in the spheres that correspond to their skills and interests. Such a personality-oriented education can be achieved by means of individualized teaching. The latter tends to be applied in class by means of differentiated learning and instruction that is also defined as students' grouping by a criterion. Among such individual characteristics as motives and emotions, cognitive processes are of the greatest importance in the context of studying new information, its perception and reproduction. Due to the fact that effective studying depends on how well new information is percepted, it is necessary to mind student's dominant perceptual modality while its presentation. According to the recent research, learners with more developed auditory perceptual modality are audials, who percept information primarily with their hearing; visual perception corresponds to visuals, for they absorb it with their visual analyzers; kinesthetic learners are successful learning something if they are free with the movements and emotions. The purpose of this article is to investigate the differentiated development of 
the English-speaking interactional competence by dominant perceptual modality. The results of the research show that the differentiated development of the English-speaking interactional competence by dominant perceptual modality can be theoretically proved and applied in practice by means of the introduction of a model dialogue. However, it is also proved that due to cross-modality that is common for students, it is recommended to activate several ways of perception simultaneously. As a conclusion, besides other investigated personalityoriented types of differentiated learning and instruction, receptive-cognitive differentiation can be distinguished. Key words: individualization, differentiated learning (instruction and assessment), speaking interaction competence, perceptual modality, model dialogue.

Постановка проблеми. Згідно із законом “Про освіту” від 05.09.2017 р. одним із принципів освітньої діяльності в Україні є принцип людиноцентризму, за яким освітній процес у закладі вищої освіти має відбуватись з урахуванням індивідуальних особливостей студента. Проте нестача матеріально-технічного забезпечення, низький рівень сформованості у студентів умінь самостійної роботи, недостатня кількість навчальних годин унеможливлюють реалізацію індивідуалізованого підходу до навчання кожного студента академічної групи.

3 метою вирішення цієї проблеми в наших попередніх дослідженнях ми запропонували застосовувати диференційований підхід до навчання іноземних мов, зокрема до формування у студентів-філологів компетентності в англомовному діалогічному мовленні. Диференціація передбачає попередній розподіл студентів на типологічні підгрупи (за певним критерієм) i ïx подальше навчання засобами, ефективнішими для тієї чи іншої групи. Слідом за І. О. Зимньою (2004) й О. Б. Бігич (2014) у контексті особистісно-діяльнісного підходу до навчання іноземних мов ми висловили думку, що критерії диференційованого навчання іноземних мов стосуються особистісної чи діяльнісної ліній розвитку студента. В такий спосіб ми виокремили особистісну й діяльнісну диференціації та їхні підвиди. Зокрема ми теоретично обгрунтували такі підвиди особистісної диференціації формування у майбутніх учителів англомовної компетентності в діалогічному мовленні, як емоційна й мотивувальна диференціація

Проте ми ще не дослідили потенціал такого складника особистісного компонента особистіснодіяльнісного підходу, як пізнавальні (когнітивні) процеси, які беруть участь в іншомовному діалогічному мовленні, а отже, є ще одним критерієм особистісної диференціації.

Аналіз актуальних досліджень. Вплив когнітивних процесів студентів на їхнє учіння $\epsilon$ предметом досліджень багатьох вітчизняних і зарубіжних психологів: Л. П. Аристової, Ш. І. Ганеліна, В. В. Давидова, М. І. Сникеєва, Л. В. Занкова, М. К. Кабардова, М. М. Левіної, І. Я. Лернера, В. Ф. Паламарчук, П. І. Підкасистого й ін. Такі науковці, як Л. С. Виготський, О. О. Леонтьєв, О. Р. Лурія, С. Л. Рубінштейн, досліджували взаємозв'язок пізнавальних процесів і мовлення. Роль когнітивних процесів в оволодінні іноземними мовами досліджували Є. В. Арцишевська, М. К. Кабардов, Т. М. Ширяєва й ін. Однак у цих дослідженнях мало уваги приділено проблемі диференційованого навчання іноземних мов, зокрема диференціації формування іншомовної компетентності в діалогічному мовленні за когнітивними здібностями.

Мета статті - дослідити пізнавальні процеси студентів, які беруть участь в іншомовному діалогічному мовленні, задля виокремлення когнітивної диференціації як підвиду особистісної диференціації формування англомовної компетентності в діалогічному мовленні й засоби іiі (когнітивної диференціації) реалізації.

Виклад основного матеріалу. Про ефективність індивідуалізованого й диференційованого навчання іноземних мов вітчизняні й зарубіжні дослідники почали говорити ще в минулому столітті, стверджуючи, що успішність оволодіння учнями / студентами іноземною мовою залежить від міри врахування їхніх особистих відмінностей.

Д. Девідсон й О. Д. Митрофанова стверджують, що для різних студентів будуть ефективними різні навчальні технології, вибір яких має грунтуватись на індивідуально-психологічних особливостях студентів, зокрема психофізіологічних механізмах, які впливають на індивідуальний 
стиль оволодіння іноземною мовою. М. К. Кабардов й С. В. Арцишевська також виокремлюють психічні процеси й уроджені нервові процеси як індивідуальні особливості студентів, що впливають на успішність вивчення іноземної мови (Кабардов, 1996, с. 39). Л. Якобовіц наголошував, що успішність оволодіння учнями / студентами іноземною мовою залежить від міри реалізації індивідуалізованого підходу до навчання, зокрема врахування емоційномотиваційної сфери студентів, а також їхніх уроджених психічних процесів (Кабардов, 1996, с. 37).

3-поміж психічних процесів розрізняють емоційно-вольові процеси й пізнавальні (когнітивні) процеси. В контексті нашого дослідження актуалізуються пізнавальні (когнітивні) процеси (увага, мислення, пам'ять, сприймання, уява) як такі, які, підсумовуючи результати попередніх досліджень, безпосередньо впливають на оволодіння іноземною мовою.

Так, від уваги учасника комунікативного акту залежить, наскільки точно буде сприйнятий, а згодом декодований іншомовний мовленнєвий матеріал. За умов комунікативного акту увага допомагає розпізнати момент, коли необхідно ініціювати чи реагувати на репліку (Ширяєва, 2009 , с. 194). На змістовий аспект висловлювання, зокрема його усвідомлення чи смислову організацію, впливає мислення. Студент із сформованою іншомовною комунікативною компетентністю може однаково добре мислити рідною й виучуваною мовами. За Т. М. Ширяєвою, аби сприйнятий мовленнєвий матеріал набув певного значення, він має бути співвіднесений 3 тією інформацією, яка попередньо зберігається у пам'яті реципієнта (короткотривалій чи довготривалій) (Ширяєва, 2009, с. 194).

Уперше проблема різних механізмів запам'ятовування інформації була виокремлена I. П. Павловим у контексті його дослідження першої й другої сигнальних систем кори головного мозку. В ході подальших досліджень взаємодії першої й другої сигнальних систем було виокремлено першосигнальні й другосигнальні засоби кодування інформації, взаємодію яких сьогодні співвідносять із взаємодією правої й лівої півкуль мозку. Так, робота правої півкулі відповідає за чуттєво-образне сприйняття реальності, а лівої півкулі - за вербально-логічне сприйняття. О. О. Белявська стверджує, що згідно з сучасними дослідженнями, пам'ять у “правопівкульних" студентів $\epsilon$ мимовільною, а в “лівопівкульних" - довільною. Так, перші не здатні запам'ятовувати силою волі, в той час як багаторазове повторення матеріалу $\epsilon$ ефективним навчальним прийомом для других (Белявська, 2015, с. 31). М. М. Вахнован зазначає, що в процесі засвоєння мовного матеріалу мислення відповідає за його смислове розуміння, а пам'ять - за фіксацію. На рівні ж мовленнєвої діяльності мислення забезпечує логічну систематизацію інформації за змістом, а пам'ять - трансформацію думок в адекватну ім мовленнєву форму (Вахнован, 2015, с. 96).

Слідом за такими науковцями, як Л. С. Виготський, І. О. Зимня, О. О. Леонтьєв, Т. В. Чернігівська, Н. Хомський та ін., М. М. Вахнован стверджує, що діяльність усіх описаних нами пізнавальних процесів реалізується в двох етапах мовлення - сприйманні (рецепціі) й відтворенні (репродукції) (Вахнован, 2015, с. 98). За О. О. Белявською (2015), сприймання іншомовного матеріалу $є$ одним із чинників його успішного засвоєння. Під сприйманням (рецепцією) розуміють суб'єктивне відображення об' єктивної реальності, зумовлене впливом предметів чи явищ на сенсорні подразники (Лозова, 2010, с. 19).

Так, вагомого значення набувають сенсорні модальності, які О. О. Белявська визначає як суб'єктивні засоби, за допомогою яких у ментальному досвіді людини відтворюється навколишній світ залежно від домінування певної модальності (слухової, зорової, кінестетичної тощо) (Белявська, 2015, с. 31). Залежно від домінувального сенсора сприйняття реальності розрізняють аудіалів, візуалів, кінестетиків, дігіталів (логіки, дискрети). Так, провідним рецептивним каналом для аудіалів є слуховий; візуали потребують зорового опертя; кінестетики краще сприймають мовленнєвий потік, спираючись на відчуття (дотики, температуру навколишнього середовища тощо), дігітали, яких також називають логіки чи дискрети, сприймають 
інформацію шляхом міркувань.

Ефективність формування у студентів компетентності в іншомовному діалогічному мовленні зумовлена рівнем сформованості їхніх рецептивних мовленнєвих навичок, зокрема навичок в аудіюванні іншомовного тексту. Так, активізація слухового каналу сприйняття $є$ обов'язковою умовою формування умінь іншомовного діалогічного мовлення у студентів 3 будь-якою домінувальною сенсорною модальністю. За таких умов сприйняття й оброблення навчального матеріалу студентами-візуалами, -кінестетами, -дігіталами буде гіршим порівняно зі студентамиаудіалами.

Кожен з чотирьох етапів формування іншомовної компетентності в діалогічному мовленні (оволодіння репліками; оволодіння діалогічними єдностями; оволодіння міні-діалогом; оволодіння діалогом) передбачає активізацію й взаємодію рецептивних каналів студентів, зокрема слухового й зорового. Ступінь і поетапність їх активізації залежать від обраних викладачем підходу і засобів навчання іншомовного діалогічного мовлення.

3-поміж підходів до навчання діалогічного мовлення виокремлюють дедуктивний підхід “зверху - вниз” й індуктивний підхід “знизу - вверх”. Перший підхід передбачає попереднє ознайомлення студентів з діалогом-зразком 3 його наступними трансформаціями й створення власних діалогів. У контексті другого підходу за допомогою навчальних опор студенти спочатку засвоюють елементи діалогу (репліки, діалогічні єдності), після чого трансформують їх й об’єднують у власні міні-діалоги й діалоги, що, однак, за В. В. Черниш $(2012$, с. 19), не виключає демонстрації діалогу-зразка. Отже, за будь-яким із цих двох підходів сприймання навчального матеріалу може відбуватися засобом діалогу-зразка, застосування якого, як було зазначено нами раніше, має відбуватися з урахуванням провідного рецептивного каналу кожного студента.

Таким чином, у контексті диференційованого формування у студентів іншомовної компетентності в діалогічному мовленні актуалізується необхідність діагностувати їхній домінувальний тип сенсорної модальності для подальшого розподілу студентів у типологічні підгрупи з умовними назвами «аудіали», «візуали», «кінестетики». Задля цього в першому семестрі (жовтень-листопад) 2018-2019 н. р. ми провели анкетування студентів-філологів Київського національного лінгвістичного університету. В анкетуванні взяли участь 30 студентівфілологів факультету сходознавства, яким був запропонований опитувальник діагностики домінувальної перцептивної модальності, розроблений С. Єфремцевим. Приклад опитувальника

\begin{tabular}{|c|c|}
\hline $\begin{array}{r}\text { Анкета } \\
\text { для визначення домінувальної перце } \\
\text { Прізвище, ім'я }\end{array}$ & $\begin{array}{l}\text { вної модальності } \\
\text { дента }\end{array}$ \\
\hline $\begin{array}{l}\text { Шановний студенте! Внаслідок заповнення цієї } \\
\text { провідний канал сприйняття: слуховий, зоровий } \\
\text { краще оволодіти іноземною мовою. } \\
\text { Інструкція. Прочитайте запропоновані твердже } \\
\text { "+", якщо погоджустесь } 3 \text { цими твердженнями, і } 3\end{array}$ & $\begin{array}{l}\text { сети Ви дізнастесь, який у Вас } \\
\text { тактильний, що допоможе Вам } \\
\text { Поставте біля кожного знак } \\
\text { «-», якщо не погоджуєтесь. }\end{array}$ \\
\hline $\begin{array}{l}\text { 1. Люблю спостерігати за хмарами і зірками. } \\
\text { 2. Часто наспівую собі потихеньку. }\end{array}$ & \\
\hline $\begin{array}{l}\text { 3. Не визнаю моду, яка незручна. } \\
\text { 4. Люблю ходити в сауну. }\end{array}$ & \\
\hline 5. Колір авто має значення для мене. & \\
\hline $\begin{array}{l}\text { 6. Дізнаюся по кроках, хто увійшов в приміщення. } \\
\text { 7. Мене розважає наслідування діалектам. }\end{array}$ & \\
\hline $\begin{array}{l}\text { 8. Зовнішньому вигляду надаю серйозного значення. } \\
\text { 9. Мені подобається приймати масаж. } \\
\text { 10. Коли є час, люблю спостерігати за людьми. }\end{array}$ & - \\
\hline
\end{tabular}


11. Погано почуваюся, коли не насолоджуюся рухом.

12. Побачивши одяг у вітрині, знаю, чи мені буде добре в ньому.

13. Коли почую стару мелодію, до мене повертається минуле.

14. Люблю читати під час прийому їжі.

15. Люблю поговорити по телефону.

16. У мене є схильність до надмірної ваги.

17. Віддаю перевагу слухати розповідь, яку хтось читає, ніж читати самому.

18. Після поганого дня мій організм напружений.

19. Охоче і багато фотографую.

20. Довго пам'ятаю, що мені сказали приятелі або знайомі.

21. Легко можу віддати гроші за квіти, тому що вони прикрашають життя.

22. Увечері люблю прийняти гарячу ванну.

23. Намагаюся записувати свої особисті справи.

24. Часто розмовляю з собою.

25. Після тривалої їзди на машині довго приходжу до тями.

26. Тембр голосу багато мені говорить про людину.

27. Надаю значення манері одягатися, яка властива іншим.

28. Люблю потягатися, розправляти кінцівки, розминатися.

29. Занадто тверде або занадто м'яке ліжко для мене мука.

30. Мені нелегко знайти зручне взуття.

31. Люблю дивитися теле- і відеофільми.

32. Навіть через роки можу впізнати особу, яку коли-небудь бачив(-ла).

33. Люблю ходити під дощем, коли краплини стукають по парасольці.

34. Люблю слухати, коли говорять.

35. Люблю займатися рухливим спортом або виконувати будь-які рухові вправи, іноді і потанцювати.

36. Коли близько цокає годинник, не можу заснути.

37. Я маю непогану музичну апаратуру/гарнітуру.

38. Коли слухаю музику, відбиваю такт ногою.

39. На відпочинку не люблю оглядати пам'ятники архітектури.

40. Не люблю безлад.

41. Не люблю синтетичні тканини.

42. Вважаю, що атмосфера в приміщенні залежить від освітлення.

43. Часто ходжу на концерти.

44. Потиск/дотик до руки особи багато говорить мені про неї.

45. Охоче відвідую галереї і виставки.

46. Серйозна дискусія - це цікаво.

47. Через дотик можна сказати значно більше, ніж словами.

48. У шумі не можу зосередитися.

подано на рис. 1.

Рис. 1. Опитувальник для визначення домінувальної перцептивної модальності

Унаслідок анкетування виявлено 46\% “аудіалів”, 33\% “візуалів”, 21\% “кінестетиків”. Проте рецептивну систему більшості опитаних студентів можна вважати полімодальною з незначним переважанням зорового чи слухового рецептивного каналу. Спираючись на результати анкетування, слідом за О. О. Белявською (2015, с. 34), вважаємо, що, задля успішного засвоєння студентами нового матеріалу, подання навчальної інформації має бути полімодальним, але з урахуванням особливостей домінувальної перцептивної системи.

Отримані результати підтверджують доцільність диференційованого формування іншомовної компетентності в діалогічному мовленні за рецептивно-когнітивним критерієм й уможливлюють 
виокремлення рецептивно-когнітивного виду диференціації як підвиду особистісної диференціації формування іншомовної компетентності в діалогічному мовленні. Засобом iï (рецептивнокогнітивної диференціації) реалізації є спосіб презентації діалогу-зразка у виокремлених типологічних підгрупах: “аудіали”, “візуали”, “кінестетики”.

Так, задля реалізації полімодальності подання навчальної інформації пропонуємо всім типологічним групам студентів запропонувати не лише обов'язковий до прослуховування аудіозапис діалогу-зразка, а також його друкований варіант. “Аудіали” спершу слухають діалогзразок, а потім уголос, застосовуючи голосові модуляції, зачитують друкований варіант. "Візуали” слухають діалог-зразок після попереднього читання його друкованого варіанта, в якому різними кольорами, шрифтом чи іншими невербальними засобами виділено ініціативні й реактивні репліки, мовленнєві кліше тощо. “Кінестетики” спершу слухають, а потім розігрують діалогзразок, супроводжуючи читання вголос друкованого тексту рухами й емоціями. В такий спосіб реалізується полімодальність подання навчальної інформації, проте первинне сприйняття відбувається через активізацію домінувальної перцептивної модальності.

Висновки й перспективи подалыших розвідок. Таким чином, унаслідок анкетування підтвердилась можливість виокремлення рецептивно-когнітивної диференціації формування у студентів іншомовної компетентності в діалогічному мовленні. Засобом діагностики рецептивнокогнітивної диференціації є анкета, засобом реалізації - спосіб презентації діалогу-зразка.

Проте мають бути враховані й інші пізнавальні (когнітивні) процеси, задіяні в іншомовному діалогічному мовленні й виокремлені нами за типом домінувальної півкулі: “правопівкульні лівопівкульні” й за типом запам'ятовування: “мимовільне - довільне запам'ятовування”. Тому перспективу подальших наукових розвідок вбачаємо у теоретичному обгрунтуванні й виокремленні інших підвидів когнітивної диференціації, а також засобів їх реалізації для формування в майбутніх учителів іншомовної компетентності в діалогічному мовленні.

\section{ЛІТЕРАТУРА}

Белявська, О. О. (2015). Перцептивні стилі - запорука ефективного навчання. Педагогічна освіта: теорія і практика, 18, 30-36.

Бігич, О. Б. і Щербина, М. Б. (2017). Особистісно-діяльнісний підхід до формування іншомовної комунікативної компетентності. В Аспекти гуманізуючого впливу освіти на особистість. Матеріали міжнародної науково-практичної конференції до 100-річчя Дніпровського національного університету імені Олеся Гончара, 25-27 жовт. (сс. 76-78). Дніпро: Літограф.

Бігич, О. Б. і Щербина, М. Б. (2017). Формування англомовної компетентності в діалогічному мовленні майбутніх учителів: емоційна диференціація. В Тенденції та перспективи розвитку науки і освіти в умовах глобалізації (сс. 274-276). Переяслав-Хмельницький.

Бігич, О. Б., Волошинова, М. М., Глазунов, М. С., Майєр, Н. В., Мацнєва, О. А., Коробейнікова, Т. І., ... Ярошенко, О. В. (2014). Сучасний студент у контексті особистіснодіяльнісного підходу: за результатами науково-методичних досліджень [колективна монографія]. Київ, Україна: Вид. центр КНЛУ.

Вахнован, М. М. (2015). Взаємозв'язок мовлення та пізнавальної сфери студентів у контексті оволодіння іноземною мовою. Проблеми сучасної психологіï, 27, 91-102.

Зимняя, И. А. (2004). Педагогическая психология. Москва: Логос.

Кабардов, М. К., Арцишевская, Е.В. (1996). Языковые и коммуникативные способности и компетенции. Вопросы психологии, 1, 34-49.

Лозова, О.М.(2010). Психологічні аспекти засвоєння іноземної мови. Київ.

Черниш, В. В. (2012). Навчання іншомовного діалогічного мовлення в аспекті компетентнісного підходу. Іноземні мови, 4, 11-27.

Ширяєва, Т. М. (2009). Психолінгвістичні особливості розвитку когнітивної сфери студентів засобами іноземної мови. Наукові записки [Національного університету "Острозька 
академія"]. Серія : Психологія і педагогіка, 12, 189-196.

Щербина, М. Б. (2017). Мотивувальна диференціація формування компетентності в англійському діалогічному мовленні : теоретичне обгрунтування й засоби реалізації. Вісник Київського начіонального лінгвістичного університету. Серія Педагогіка та психологія, 28, 48-55.

\section{REFERENCES}

Beliavs'ka, O. O. (2015). Pertseptyvni styli - zaporuka efektyvnoho navchannia. Pedahohichna osvita: teoriia i praktyka, 18, 30-36.

Bihych, O. B. i Scherbyna, M. B. (2017). Osobystisno-diial'nisnyj pidkhid do formuvannia inshomovnoi komunikatyvnoi kompetentnosti. V Aspekty humanizuiuchoho vplyvu osvity na osobystist'. Materialy mizhnarodnoi naukovo-praktychnoi konferentsii do 100-richchia Dniprovs'koho natsional'noho universytetu imeni Olesia Honchara, 25-27 zhovt. (ss. 76-78). Dnipro: Litohraf.

Bihych, O. B. i Scherbyna, M. B. (2017). Formuvannia anhlomovnoi kompetentnosti v dialohichnomu movlenni majbutnikh uchyteliv: emotsijna dyferentsiatsiia. V Tendentsii ta perspektyvy rozvytku nauky i osvity v umovakh hlobalizatsii (ss. 274-276). Pereiaslav-Khmel'nyts'kyj.

Bihych, O. B., Voloshynova, M. M., Hlazunov, M. S., Majier, N. V., Matsnieva, O. A., Korobejnikova, T. I., ... Yaroshenko, O. V. (2014). Suchasnyj student u konteksti osobystisnodiial'nisnoho pidkhodu: za rezul'tatamy naukovo-metodychnykh doslidzhen' [kolektyvna monohrafiia]. Kyiv, Ukraina: Vyd. tsentr KNLU.

Vakhnovan, M. M. (2015). Vzaiemozv'iazok movlennia ta piznaval'noi sfery studentiv u konteksti ovolodinnia inozemnoiu movoiu. Problemy suchasnoi psykholohii, 27, 91-102.

Zymniaia, Y. A. (2004). Pedahohycheskaia psykholohyia. Moskva: Lohos.

Kabardov, M. K., Artsyshevskaia, E.V. (1996). Yazykovye y kommunykatyvnye sposobnosty y kompetentsyy. Voprosy psykholohyy, 1, 34-49.

Lozova, O. M. (2010). Psykholohichni aspekty zasvoiennia inozemnoi movy. Kyiv.

Chernysh, V. V. (2012). Navchannia inshomovnoho dialohichnoho movlennia v aspekti kompetentnisnoho pidkhodu. Inozemni movy, 4, 11-27.

Shyriaieva, T. M. (2009). Psykholinhvistychni osoblyvosti rozvytku kohnityvnoi sfery studentiv zasobamy inozemnoi movy. Naukovi zapysky [Natsional'noho universytetu "Ostroz'ka akademiia"]. Seriia : Psykholohiia i pedahohika, 12, 189-196.

Scherbyna, M. B. (2017). Motyvuval'na dyferentsiatsiia formuvannia kompetentnosti v anhlijs'komu dialohichnomu movlenni : teoretychne obgruntuvannia j zasoby realizatsii. Visnyk Kyivs'koho natsional'noho linhvistychnoho universytetu. Seriia Pedahohika ta psykholohiia, 28, 48-55. 